\title{
Developing an E-Module Physics-Based Kvisoft Flipbook Maker to Enhance the Concept of Understanding for the Senior High School Student
}

\author{
Mika Dwi Permata ${ }^{1, *}$ Ardila Safitri ${ }^{1}{ }^{1}$ Jumadi $^{2}$ \\ ${ }^{I}$ Master of Physics Education, Faculty of Mathematics and Natural Sciences, Universitas Negeri Yogyakarta, \\ Indonesia \\ ${ }^{2}$ Department of Natural Science Education, Faculty of Mathematics and Natural Sciences, Universitas Negeri \\ Yogyakarta, Indonesia \\ "Corresponding author. Email: mikadwi.19@student.uny.ac.id
}

\begin{abstract}
This pilot paper aimed to develop a kvisoft flipbook maker-based e-module Physics for global warming symptomatic material as a physics supplementary teaching material for the eleventh-grade student. The research adopted the model of 4D development stood for Define, Design, Develop, and Disseminate. The subjects of this study were 31 students of Mathematics and Science of Senior High School of 1 PAKEM. The research instruments employed were preliminary study questionnaires, material expert validation survey form, media expert validation survey form. The methods of data collection employed were validation, observation, pretest, posttest, and study of documentation. Data Analyzing Technique utilized was the Sign Test. The results of the paper showed that 1) the KFM-based Physics e-module developed belonged to a valid category and was worth to use. 2) Understanding students' concepts during learning activities has increased significantly.
\end{abstract}

Keywords: E-module, Kvisoft flipbook maker, Understanding concepts

\section{INTRODUCTION}

Generally, the concept of understanding skill becomes a critical factor in learning. Students can develop their skills by understanding the concept of each subject matter [1]. Physics is one of the fields of science that requires good conceptual understanding and trains learners to think constructively, analytically, logically, and systematically [2]. Learning physics is considered difficult due to learning-oriented on various representations that are still abstract [3]. Understanding the concept of incorrect abstract material is able to lead to misconceptions among students, making teachers often have difficulty conveying abstract materials [4].

Besides, the advancement of science and technology is a challenge for teachers in presenting teaching materials during the learning process. Teachers are expected to be able to integrate technology into the learning process. This is by the era of industry revolution 4.0 which is more prioritizes ITbased information [5] Learning resources should be made interesting and can be applied to technology to help teachers in generating the students' interest in reading, so students can easily understand the concepts they learned [6]. Teaching materials that were originally printed can be developed in digital form or better known as electronic modules (E-modules).

Furthermore, modules can act as supplementary, complementary, and substitution [7]. Currently, the module is still verbal or textual, which makes students not interested in reading it. For students to read and understand it, it is necessary to develop modules with drawings and illustrations. E-modules are examples of learning resources and media that facilitate selflearning and technology-based learning [8]. The emodule learning process makes students no longer dependent on teachers as the only source of information [9]. The implementation of e-modules in learning can condition activities in the classroom more planned activities in class, self-contained, complete, and the results are obvious [10]. The e-modules has several advantages compared to the print module, such as being more interactive, able to load images, videos, 
and animations, and can be used anywhere and anytime, making it more practical to carry anywhere.

As known, the e-module is a combination of print media and computers, so that electronic modules can present an attractive appearance, complete information, and has a high level of interactivity. [11]. The creative design of multimedia-based learning media is done using open-source software, for example, Kvisoft Flipbook Maker (KFM), which is used to make teaching materials into electronic books, electronic flipbooks [12]. Using the KFM as a learning medium is expected to create fun learning, increase interest in learning, motivate to encourage learning, and have a psychological impact on students. [13].

KFM is a software designed to convert PDF files to digital. This software transforms the appearance of PDF files into more interesting such a book in digital form [14]. KFM is not fixated only on writings but can include motion, video, and audio animation which can make interactive learning so that learning did not become monotonous. KFM turns books or other teaching materials into digital electronic books in the form of flipbooks [13]. To build e-module using KFM is simpler be able accessed online or offline.

Physics lessons are considered elusive because many abstract formulas and physicist phenomena are difficult to understand. Learning like this is less interactive and fun for students. Students are less actively involved in the learning process. Students' self-potential cannot be developed if the learner is inactive in learning. The activeness can be achieved by using teaching materials that are innovative, varied, interesting, contextual, and in accordance with the level of needs of students. The flipbook application can be accessed by gadgets and laptops, making this application a recommendation to be developed. Additionally, as a tool in learning activities, flipbooks can also give changes to students such as improving learning outcomes, motivation, and attitude of students [15].

This paper will discuss the issue of development in the form of physics teaching materials integrated with e-models based on KFM to improve understanding of student concepts. Physics an e-module that can be studied anywhere and anytime is expected to facilitate student learning.

\section{RESEARCH METHOD}

\subsection{Studies of Place and Time}

The study was conducted in May 2020 at Senior High School of 1 PAKEM, Yogyakarta. This research was conducted in the 2019/2020 school year, class XI semester 2 .

\subsection{Participant}

The subject of this study was students of the eleventh grade in Mathematics and Science (MIPA) 1 at Senior High School of 1 PAKEM. The research was conducted in one class namely XI MIPA 1 as an experimental class numbered 31 people.

\subsection{Instrument}

Research instruments are carried out through the evaluation process by experts and physics lecturers. Instruments are evaluated in terms of materials and language. Another aspect tested is its feasibility. Instrument tests are conducted to obtain empirical validity and reliability tests.

\subsection{Studies Procedure}

The study was research development. The model to develop was used as 4-D models comprising of Define, Design, Develop, and Disseminate which include the defining, planning, developing, and deploying stage. The Design stage was to find the problems in learning [16]. This stage consisted of an analysis of students' needs based on student characteristics, analysis of the subject matter, and curriculum. The stage of planning was to make a draft E-module on symptom material and global warming. While the development stage was to result in the KFM-based Physics E-modules. The presentation of abstract material will be easier to understand using KFM. Assessment of research results conducted before and after learning aimed to find out the differences in learning in the experiment group. Emodule developed effectively after being able to improve students' learning outcomes. The deployment stage for the deployment of E-module Physics based on KFM is widespread.

\subsection{Analysing Data}

Data obtained through research instruments is analyzed using SPSS. Analysis with SPSS was an obligation to ensure that distributed data was normal and homogeneous. Descriptive data obtained from validators used to determine the validity and reliability of research instruments. The $\mathrm{V}^{\prime}$ Aiken equation was employed to make sure the validity of the research instruments. Analysis of the validity of research instruments was measured by calculating the score of each aspect of the assessment with the formula: 


$$
\mathrm{V}=\frac{\sum \mathrm{s}}{[\mathrm{n}(\mathrm{c}-1)]}
$$

$s=r-l_{0}, l_{0}$ is the lowest validity rating, $c$ is the highest validity rating, and $r$ is the score given by the validator. The validity level of the e-module developed using the assessment qualification criteria based on Table 1 [17].

Table 1. The criteria of validity

\begin{tabular}{|l|l|}
\hline Validity Result & Validity Criteria \\
\hline $0.8<\mathrm{V} \leq 1$ & Very Adequate \\
\hline $0.6<\mathrm{V} \leq 0.8$ & Adequate \\
\hline $0.4<\mathrm{V} \leq 0.6$ & Less Adequate \\
\hline $0.2<\mathrm{V} \leq 0.4$ & Inadequate \\
\hline
\end{tabular}

The next step of instrument reliability to evaluate the developed product is determined using kappa Cohen analysis. The learning device product feasibility analysis is done by calculating the average score of each aspect using the following formula [4].

$\overline{\mathrm{x}}=\frac{\sum \mathrm{x}}{\mathrm{n}}$

with $\overline{\mathrm{x}}$ is the average score of each indicator, $n$ was the number of raters, and $\Sigma \mathrm{x}$ was the total score of each indicator. The assessment criteria for KFM-based physics e-modules are shown in Table 2.

Table 2. KFM-based physics e-module assessment criteria

\begin{tabular}{|c|l|}
\hline \multicolumn{1}{|l|}{ Score } & Category \\
\hline$X>\bar{X}_{i}+1.8 s b_{i}$ & Very Good \\
\hline $\bar{X}_{i}+0.6 s b_{i}<X \leq \bar{X}_{i}+1.8 s b_{i}$ & Good \\
\hline $\bar{X}_{i}-0.6 s b_{i}<X \leq \bar{X}_{i}+0.6 s b_{i}$ & Good Enough \\
\hline $\bar{X}_{i}-1.8 s b_{i}<X \leq \bar{X}_{i}-0.6 s b_{i}$ & Less Good \\
\hline$X \leq \bar{X}_{i}-1.8 s b_{i}$ & Very Less Good \\
\hline
\end{tabular}

$\overline{\mathrm{X}}$ is the actual score, $\bar{X} i$ is the average ideal score which $\frac{1}{2}$ (ideal maximum score + ideal minimum score), and $\mathrm{SB}_{\mathrm{i}}$ is the ideal standard deviation which $\frac{1}{6}$ (ideal maximum score - ideal minimum score).

The form of research is a pre-experimental design with one group pretest-posttest design as shown in Table 3.

Table 3. One group pre-test post-test design

\begin{tabular}{|l|l|l|}
\hline Pre-test & Treatment & Post-test \\
\hline $\mathrm{O}_{1}$ & $\mathrm{X}_{1}$ & $\mathrm{O}_{2}$ \\
\hline
\end{tabular}

$\mathrm{O}_{1}$ was the pretest, $\mathrm{O}_{2}$ was the posttest, $\mathrm{X}_{1}$ was a class in which used the KFM-based physics e- modules. The e-modules developed were applied to the experiment class. Data obtained from the pretest and posttest were analyzed descriptively and quantitatively. Each improvement in learning achieved is determined by calculating each student's test score. The effect of KFM-based physics emodules on improving the concept of learners was analyzed with descriptive statistics and sign test using the SPSS program. The average increase in concept understanding could be calculated by using the normalization of profit equations (N-Gain) [18]. The category of $\mathrm{N}$-gain provide in Table 4.

$$
\mathrm{N}-\text { Gain }=\frac{\mathrm{s}_{\text {posttest }}-\mathrm{s}_{\text {pretest }}}{\mathrm{s}_{\text {max }}-\mathrm{s}_{\text {pretest }}} \times 100 \%
$$

\begin{tabular}{|c|c|c|}
\hline No & Limit & Category \\
\hline 1 & $g>70$ & High \\
\hline 2 & $30 \leq g \leq 70$ & Medium \\
\hline 3 & $g<30$ & Low \\
\hline
\end{tabular}

Table 4. N-gain level criteria

\section{RESULTS AND DISCUSSION}

The result of this research is in the form of physics teaching materials integrated with the KFM-based emodule. The e-module developed for global warming material. The developed module is expected to facilitate the learning process anywhere and anytime, and students' understanding of concepts can improve.

This stage of research is limited by product validation. A product that is valid and feasible to use under the validator's assessment. Validators are conducted by media expert lecturers, material expert lecturers, and field practitioners. A product that is valid and feasible to use following the validator's assessment. The results of the V Aiken calculation stipulate that KFM-based physics modules and research instruments are valid. The validation levels are shown in Table 5.

Table 5. Results of data collection instrument validity

\begin{tabular}{|l|l|l|l|}
\hline No & $\begin{array}{l}\text { Data } \\
\text { Collection } \\
\text { Instrument }\end{array}$ & $\begin{array}{l}\text { V Aiken } \\
\text { Coefficient }\end{array}$ & Explanation \\
\hline 1 & $\begin{array}{l}\text { Assessment of } \\
\text { learning } \\
\text { instruments }\end{array}$ & 1 & $\begin{array}{l}\text { Very } \\
\text { Adequate }\end{array}$ \\
\hline
\end{tabular}




\begin{tabular}{|l|l|l|l|}
\hline 2 & $\begin{array}{l}\text { Task } \\
\text { assessment } \\
\text { sheet }\end{array}$ & 1 & $\begin{array}{l}\text { Very } \\
\text { Adequate }\end{array}$ \\
\hline
\end{tabular}

The assessment results of the KFM-based physics e-module by media and materials experts are presented in Table 6.

Table 6. Results of physics e-module on KFM assessment

\begin{tabular}{|c|c|c|c|}
\hline No & Aspect & $\begin{array}{l}\text { Assessment } \\
\text { Result }\end{array}$ & Explanation \\
\hline 1 & $\begin{array}{l}\text { Media Expert } \\
\text { Navigation } \\
\text { Learning } \\
\text { media display }\end{array}$ & $\begin{array}{l}2.82 \\
2.94\end{array}$ & $\begin{array}{l}\text { Very Good } \\
\text { Very Good }\end{array}$ \\
\hline 2 & $\begin{array}{l}\text { Material } \\
\text { Expert } \\
\text { Learning } \\
\text { competency } \\
\text { Material } \\
\text { Task }\end{array}$ & $\begin{array}{l}2.96 \\
2.85 \\
2.88\end{array}$ & $\begin{array}{l}\text { Very Good } \\
\text { Very Good } \\
\text { Very Good }\end{array}$ \\
\hline & Average score & 2.89 & Very Good \\
\hline
\end{tabular}

Table 6 it showed that the rating score of media assessments by validators experts is 2.89 with excellent categories. The assessment results showed that KFM-based physics e-modules are worth implementing in learning. A display of KFM-based physics e-modules developed on global warming symptom materials is shown in Figure 1 and Figure 2.

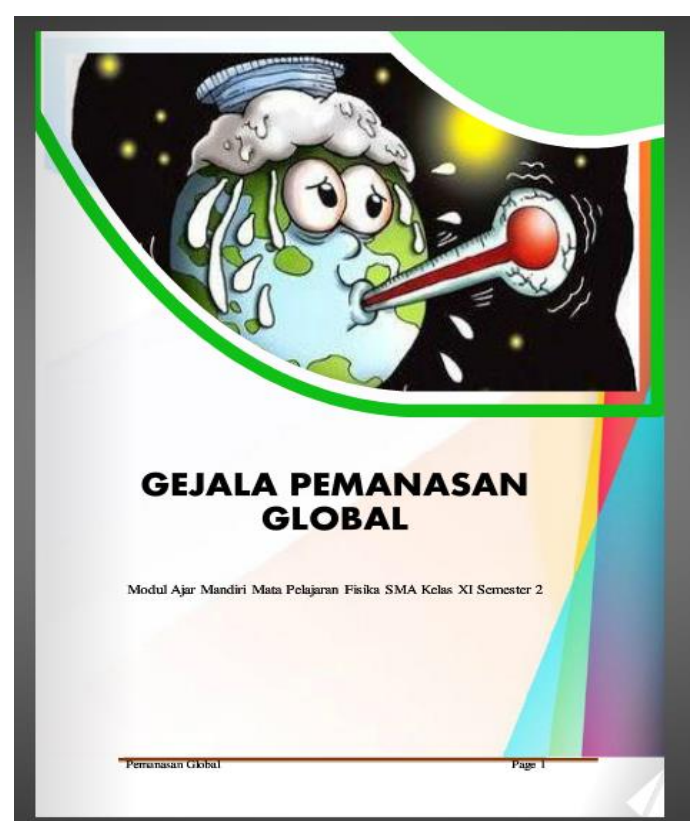

Figure 1 First page of physics e-module based on KFM

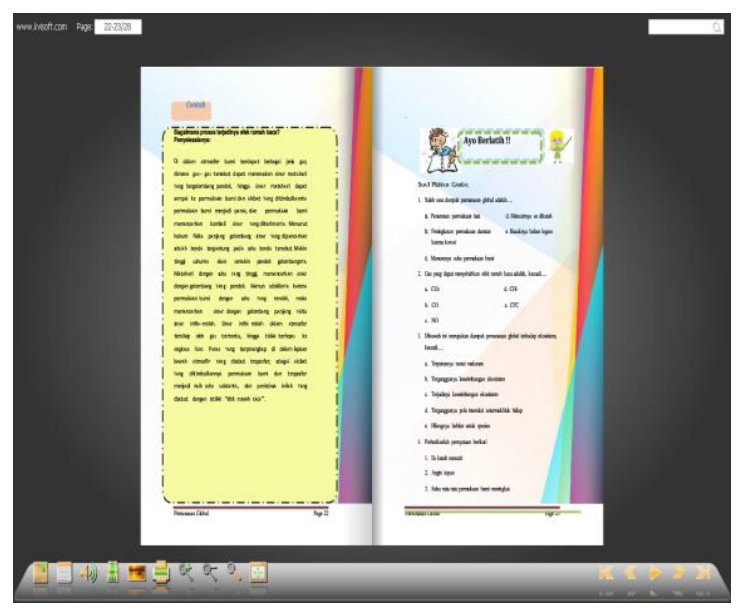

Figure 2 Content of physics e-module based on KFM

The KFM-based physics e-module display in Figure 1 and Figure 2 display the main view of the title of the studied material, examples of how the greenhouse effect occurs, and the display of cognitive tests at the end of each learning activity.

In the development test of E-Module Physics assisted by KFM, the understanding of the concept is measurable for students through pretest and posttest activities conducted at the beginning and the end of the meeting. The students' concept understanding measurement data obtained aims to test the effectiveness of the KFM-assisted Physics Module EModules on global warming symptomatic materials. Measurement results data are analyzed using descriptive statistics. The results of the analysis of the effectiveness of E-Module Physics in improving students' understanding of concepts are shown in Table 7.

Table 7. Descriptive statistics the understanding of students' concept

\begin{tabular}{|l|c|c|c|c|c|}
\hline & N & Min & Max & Mean & $\begin{array}{c}\text { Std. } \\
\text { Deviation }\end{array}$ \\
\hline Pre-test & 31 & 45 & 78 & 61.94 & 7.456 \\
Post-test & 31 & 64 & 98 & 84.90 & 8.047 \\
Valid N & 31 & & & & \\
(list-wise) & & & & & \\
\hline
\end{tabular}

The average posttest score is higher than the average pretest value indicating an increase. Thus, it can be concluded that students' conceptual understanding before and after learning with the applied innovation is different. Next the data is 
analyzed using the Sign Test. The first Sign test output result is a frequency table (seen Table 8).

Table 8. Frequency of the understanding of students' concepts

\begin{tabular}{|l|l|c|}
\hline & & N \\
\hline Post-test - & Negative Differences $^{\text {a }}$ & 0 \\
\cline { 2 - 3 } Pre-test & Positive Differences $^{b}$ & 30 \\
\cline { 2 - 3 } & Ties $^{c}$ & 1 \\
\cline { 2 - 3 } & Total & 31 \\
\hline
\end{tabular}

a. Post-test $<$ Pre-test, b. Post-test $>$ Pre-test, c. Post-test $=$ Pre test

Table 8 explains that the overall understanding of the learners' concept is improved based on the higher posttest value of the pretest. The output results of the Sign Test data analysis are presented in Table 9.

Table 9. Sign test statistics results

\begin{tabular}{|l|c|}
\hline & Posttest - Pretest \\
\hline$Z$ & $-5.295^{\mathrm{a}}$ \\
\hline Asymp. Sig. (2-tailed) & .000 \\
\hline
\end{tabular}

The result of the statistical test using Sign Test obtained $\alpha$ of 0.00 . Because $\alpha<0.05$ then Ho was rejected, so there is an improved understanding of the concept of learners after using KFM based $e$-module Physics-based KFM.

Students' understanding of the concept that increases after being given treatment using e-module is calculated by the normalized N-Gain formula shown in Figure 3.

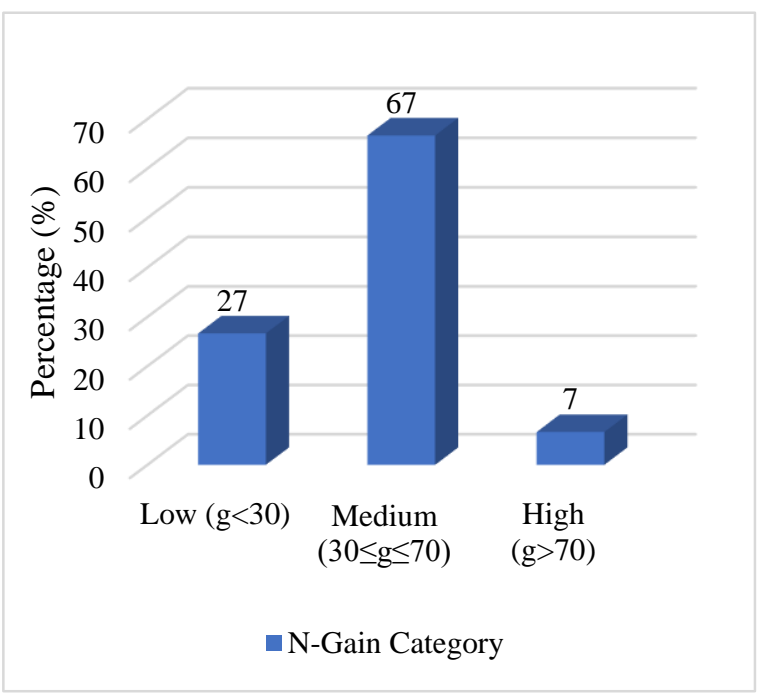

Figure 3 Improved understanding of concepts using N-Gain
In Figure 3, it shows the understanding of the students' concept in particular with the eleventh grade of MIPA 1 after using e-module Physics-based KFM appears significantly improved. From the figure, it can be seen that there is a correlation between understanding the concept and the e-module Physicsbased KFM implemented.

Consequently, students can easily access emodules anywhere and anytime. E-modules packaged in electronics allow students to be able to learn independently as they can be read using a computer or an electronic book [19]. Besides, e-modules can be interactive involving the display of audiovisuals, sound, movies, and so on in their use is easy to understand, so it can be used as a good learning medium [20].

The introduction and guidance of the KFM-based Physics e-module must really be considered so that during learning activities students do not experience difficulties in using it. This can affect the development of an optimal understanding of students' concepts. Also, the development of KFM-assisted Physics emodules needs to be applied to different materials to determine their effectiveness.

\section{CONCLUSION}

KFM-assisted Physics e-modules developed based on expert assessments of media and materials are valid and reliable to use. The learning conducted using the e-module Physics-based KFM was able to improve students' conceptual understanding. The effect of emodule Physics assisted KFM with the understanding of the concept of learners is evidenced by statistical test results using the sign test.

\section{REFERENCES}

[1] A. Shishigu, A. Hailu, Z. Anibo, Problem-Based Learning and Conceptual Understanding of College Female Students in Physics, EURASIA Journal of Mathematics, Science and Technology Education 14(1) (2018) 145-154. DOI: https://doi.org/10.12973/ejmste/78035

[2] P. Klein, J. Viiri, J. Kunh, Visual Cues Improve Students' Understanding of Divergence and Curl: Evidence From Eye Movements During Reading and Problem Solving, American Physical Society 15(1) (2019) 1-9. DOI: https://doi.org/10.1103/PhysRevPhysEducRes.1 $\underline{5.010126}$

[3] Wartono, Y.F. Alfroni, J.R. Batlolona, N. Mahapoonyanont, Inquiry-Scaffolding Learning 
Model: Its Effect on Critical Thinking Skills and Conceptual Understanding, Jurnal Ilmiah Pendidikan Fisika Al-Biruni 8(2) (2019) 249259. DOI: https://doi.org/10.24042/jipfalbiruni.v8i2.4214

[4] F.A. Yanti, H. Kuswanto, Habibi, A. Kinasih Development of Analogy-Based Material Physics Module to Provide Analogy Ability of Physics Teachers Candidates, Jurnal Pendidikan Fisika Indonesia 16(1) (2020) 34-40. DOI: https://doi.org/10.15294/jpfi.v16i1.9122

[5] Abdullah, S. Ramadhan, R. Linda, Pengembangan E-Modul Interaktif Chemistry Magazine Berbasis Kvisoft Flipbook Maker pada Materi Laju Reaksi, Jurnal Zarah 8(1) (2020) 713.

DOI: https://doi.org/10.31629/zarah.v8i1.1352

[6] H. Nufus, Susilawati, R. Linda, Implementation of E-Module Stoiciometry Based on Kvisoft Flipbook Maker for Increasing Understanding Study Learning Concepts of Class X Senior High School, Journal of Educational Sciences 4(2) (2020) 261-272. DOI: https://doi.org/10.31258/jes.4.2.p.261-272

[7] Darmawan, E-Learning Development and Design, Remaja Rosdakarya, 2014.

[8] M. N. Nigrum, N. R. Dewi, P. Parmin, Development of Pop-Up Module with Inquiry Guided-Based in The Solar System's Theme for 7th Grade Students, Jurnal Inovasi Pendidikan IPA 4(1) (2018) 1-10. DOI: https://doi.org/10.21831/jipi.v4i1.14439

[9] D. Sugianto, A.G. Abdullah, S. Elvyanti, Y. Mulyadi, Modul Virtual: Multimedia Flipbook Dasar Teknik Digital, Inovotec 9(2) (2013) 101116. DOI: https://doi.org/10.17509/invotec.v9i2.4860

[10] Linda, H. Nufus, Susilawati, The implementation of chemistry interactive e-module based on kvisoft flipbook maker to improve student' selflearning, in: The 8th International Conference of the Indonesian Chemical Society, vol. 2243, AIP Publishing, College Park, Maryland, 2019, pp. 16. DOI: https://doi.org/10.1063/5.0002309

[11] M. Wibowo, E. Gustina, S.M. Ayu, L. Sofiana, Digital Flipbook Media as A Media for Health Promotion in Youth: Research and Development, International Journal of Educational Research
Review 4 (2019) 725-733. DOI: https://doi.org/10.24331/ijere.628717

[12] S. Fahmi, S.W. Priwantoro, R.A. Cahdriyana, A. Hendroanto, S.N. Rohmah, L.C. Nisa, Interactive learning media using kvisoft flipbook maker for mathematics learning, in: Journal of Physics: Conference Series, vol. 1188, IOP Publishing, Bristol, 2019, pp 1-7. DOI: https://doi.org/10.1088/17426596/1188/1/012075

[13] N. Susanti, Yennita, Azhar, Development of Contextual Based Electronic Global Warming Modules Using Flipbook Applications as Physics Learning Media in High Schools, Journal of Educational Sciences 4(3) (2020) 541-559. DOI: https://doi.org/10.31258/jes.4.3.p.541-559

[14] N.N. Mulyaningsih, D.L. Saraswati, Penerapan Media Pembelajaran Digital Book dengan Kvisoft Flibbook Maker, Jurnal Pendidikan Fisika 5(1) (2017) 25-32. DOI: https://doi.org/10.24127/jpf.v5i1.741

[15] D.U. Mulyadi, S. Wahyuni, R.D. Handayani, Pengembangan Media Flash Flipbook untuk Meningkatkan Keterampilan Berpikir Kreatif Siswa dalam Pembelajaran IPA di SMP, Jurnal Pembelajaran Fisika 4(4) (2016) 296-301.

[16] D.P. Handayani, Jumadi, I. Wilujeng, H. Kuswanto, Development of comic integrated student worksheet to improve critical thinking ability in microscope material, in: Journal of Physics: Conference Series, vol. 1233, IOP Publishing, Bristol, 2019, pp. 1-9. DOI: https: //doi.org/10.1088/1742-6596/1233/1/012069

[17] I. Farida, Jumadi, I. Wilujeng, Senam, Developing android-based science instructional media to improve scientific literacy of junior high school students, in: Journal of Physics: Conference Series, vol. 1006, IOP Publishing, Bristol, 2018, pp. 1-10. DOI: https://doi.org/10.1088/17426596/1006/1/012034

[18] N. Sholihah, I. Wilujeng, S. Purwanti, Development of android-based learning media on light reflection material to improve the critical thinking skill of high school students, in: Journal of Physics: Conference Series, vol. 1440, IOP Publishing, Bristol, 2020, pp. 1-10. DOI: https://doi.org/10.1088/17426596/1006/1/012034 
[19] A. Aulia, Andromeda, Pengembangan E-Modul Berbasis Inkuiri Terbimbing Terintegrasi Multirepresentasi dan Virtual Laboratory pada Materi Larutan Elektrolit dan Nonelektrolit untuk Kelas X SMA/MA, EduKimia Journal 1(1) (2019) 94-102. DOI: https://doi.org/10.24036/ekj.v1.i1.a34

[20] Zahara, A. Susilowati, Meningkatkan Motivasi Belajar Peserta Didik dengan Menggunakan Media Modul Elektronik di Era Revolusi Industri 4.0, BIODIK: Jurnal Ilmiah Pendidikan Biologi 6(2) (2020) 145-158. DOI: https://doi.org/10.22437/bio.v6i2.8950 